\title{
Perancangan Alat Pelorot Malam/ Lilin Menggunakan Metode Pahl and Beitz
}

\author{
Puryani $^{* 1}$, Laila Nafisah ${ }^{2}$, Muhammad Shodiq Abdul Kanan ${ }^{3}$, Pradeas Ridiasa ${ }^{4}$ \\ ${ }^{1,2,3,4}$ Program Studi Sarjana Teknik Industri, Fakultas Teknik, UPN "Veteran" \\ Yogyakarta \\ Jln. Babarsari No. 2 Tambakbayan Sleman Yogyakarta \\ Email: "1 purya_ni@yahoo.co.id, ${ }^{2}$ lailanafisah71@gmail.com, ${ }^{3}$ mshodiqak@gmail.com, \\ pradeasridiasa@gmail.com
}

\begin{abstract}
Abstrak
Industri Batik Plalangan merupakan UKM batik yang sudah diakui oleh Dinas Perindustrian Kabupaten Sleman. Batik yang dihasilkan dari UKM ini berupa batik cap dan batik tulis. Proses pembuatan batik di UKM ini masih sangat sederhana. Pada proses pembuatan motif di kain khususnya untuk batik tulis dengan cara menggelar kain di atas pola gambar di lantai kemudian dijiplak. Pada proses pelorotan malam masih menggunakan alat yang sederhana, yaitu menggunakan panci berisi air yang direbus di atas tungku kemudian selembar kain yang sudah dibatik dimasukkan ke dalam panci tersebut sambil diaduk menggunakan tongkat kayu selama \pm 5 menit/kain. Proses tersebut beresiko cidera terkena air/uap panas dari panci dan kelelahan pada saat mengaduk kain. Oleh karena itu, penelitian ini bertujuan merancang alat pelorot malam yang praktis dan efisien. Perancangan alat dilakukan dengan menggunakan metode Pahl and Beitz. Hasil perancangan menunjukkan bahwa alat yang dikembangkan dapat mengurangi tingkat cidera dan tingkat kelelahan operator lebih rendah dari alat lama, yaitu dari 53,60\% menjadi $42,61 \%$. Selain itu alat ini dapat mempercepat waktu proses pelorotan. Penggunaan alat lama waktu rata-rata proses prlorotan malam/lembar kain selama 4,38 menit, dengan alat baru membutuhkan waktu 3,77 menit untuk 4 lembar kain batik sehingga produktivitasnya meningkat.
\end{abstract}

Kata kunci: batik, Pahl and Beitz, perancangan alat, pelorot malam/lilin

\section{PENDAHULUAN}

Industri Batik Plalangan merupakan UKM batik yang sudah diakui/ dikukuhkan oleh Dinas Perindustrian Kabupaten Sleman. UKM ini terletak di jalan Abdullah Sayuti, Plalangan Pandowoharjo, Kabupaten Sleman, Daerah Istimewa Yogyakarta. Batik yang dihasilkan dari UKM ini berupa batik cap dan batik tulis yang diberi nama Batik Ayu Arimbi. Dalam pembuatan motif batik dilakukan secara manual. Pembatikan dengan cara manual membutuhkan waktu yang cukup lama, karena ketelitian sangat diperlukan dalam proses pembuatan motif awal pada kain baik. Industri ini harus mampu menyelesaikan order dalam waktu yang sesingkat mungkin dan sesuai dengan kesepakatan konsumen.

Proses pembuatan batik memiliki beberapa tahapan. Tahap pertama adalah pembuatan gambar motif, bahan yang digunakan adalah kain katun, pola gambar atau mall, dan pensil 4B. Tahap kedua adalah pemberian malam. Malam adalah cairan lilin yang digunakan untuk menutupi motif agar tidak terkena warna saat proses pewarnaan. Tahap ketiga adalah pemberian warna batik. Tahap keempat adalah proses pencelupan. Tahap kelima adalah pelorotan malam. 
Industri Batik Plalangan dalam melakukan proses pelorotan malam masih menggunakan alat yang sederhana, yaitu menggunakan panci dan kemudian pengadukan kain menggunakan tongkat kayu \pm 5 menit/kain, jika satu kain sudah diselesaikan maka kain berikutnya baru dimulai proses pelorotan, dan begitu seterusnya, hingga semua kain yang akan diproses pelorotan selesai. Hal tersebut berdampak pada kelelahan pekerja pada saat mengaduk kain dengan menggunakan tongkat dan resiko cidera terkena air panas sangat besar. Selain itu, proses tersebut tidak praktis dan efisien saat melakukan proses pelorotan. Hal ini dapat berpengaruh pada waktu pengerjaan kain batik. Oleh karena itu, penelitian ini bertujuan merancang alat pada proses pelorotan malam yang praktis dan efisien, sehingga memudahkan pekerja dalam melakukan proses pelorotan malam/ lilin menggunakan metode Pahl and Beitz sebagaimana telah dilakukan oleh Imdaadi (2015) namun dengan obyek rancangan yang berbeda.

\section{METODE PENELITIAN}

Prosedur perancangan model Pahl and Beitz terdiri dari 4 fase (Pahl \& Beitz, 2013) sebagaimana ditampilkan pada Gambar 1. Penjelasan singkat setiap fase ialah sebagai berikut:

a. Perencanaan dan penjelasan tugas.

Tugas fase pertama adalah menyusun spesifikasi produk yang mempunyai fungsi khusus dan karakteristik tertentu yang memenuhi kebutuhan masyarakat. Hasil dari fase ini adalah spesifikasi produk yang dimuat dalam suatu daftar persyaratan teknik.

b. Perancangan konsep produk.

Berdasarkan spesifikasi produk hasil fase pertama, dicari beberapa konsep produk yang dapat memenuhi persyaratan-persyaratan dalam spesifikasi tersebut. Konsep produk tersebut merupakan solusi dari masalah perancangan yang harus dipecahkan.

c. Perancangan bentuk produk (embodiment design)

Pada fase perancangan bentuk ini, konsep produk "diberi bentuk", yaitu komponen-komponen konsep produk yang dalam gambar skema atau gambar skets masih berupa garis atau batang saja, kini harus diberi bentuk, sedemikian rupa sehingga komponen-komponen tersebut secara bersama menyusun bentuk produk, yang dalam geraknya tidak saling bertabrakan sehingga produk dapat melakukan fungsinya.

d. Perancangan detail.

Hasil akhir fase ini adalah gambar rancangan lengkap dan spesifikasi produk untuk pembuatan.

Langkah-langkah pengolahan data yang dilakukan adalah sebagai berikut:

a. Melakulan perencanaan dan penjelasan tugas, berdasarkan hasil dari kuesioner.

b. Melakukan perancangan konsep produk dengan cara (1) menyusun fungsi sistem dalam hubungan transformasi input-fungsi-output menggunakan model black box, (2) menggambarkan sub-sub fungsi dalam blok diagram dan 
batas sistem berbentuk transparent box, dan (3) merancang alternatif alat pelorot malam/ lilin.

c. Melakukan pengukuran data antropometri.

d. Merancang produk/ alat, dilakukan dengan mewujudkan konsep yang dipilih.

e. Melakukan perancangan detail.

f. Melakukan pengujian alat yang dihasilkan. 


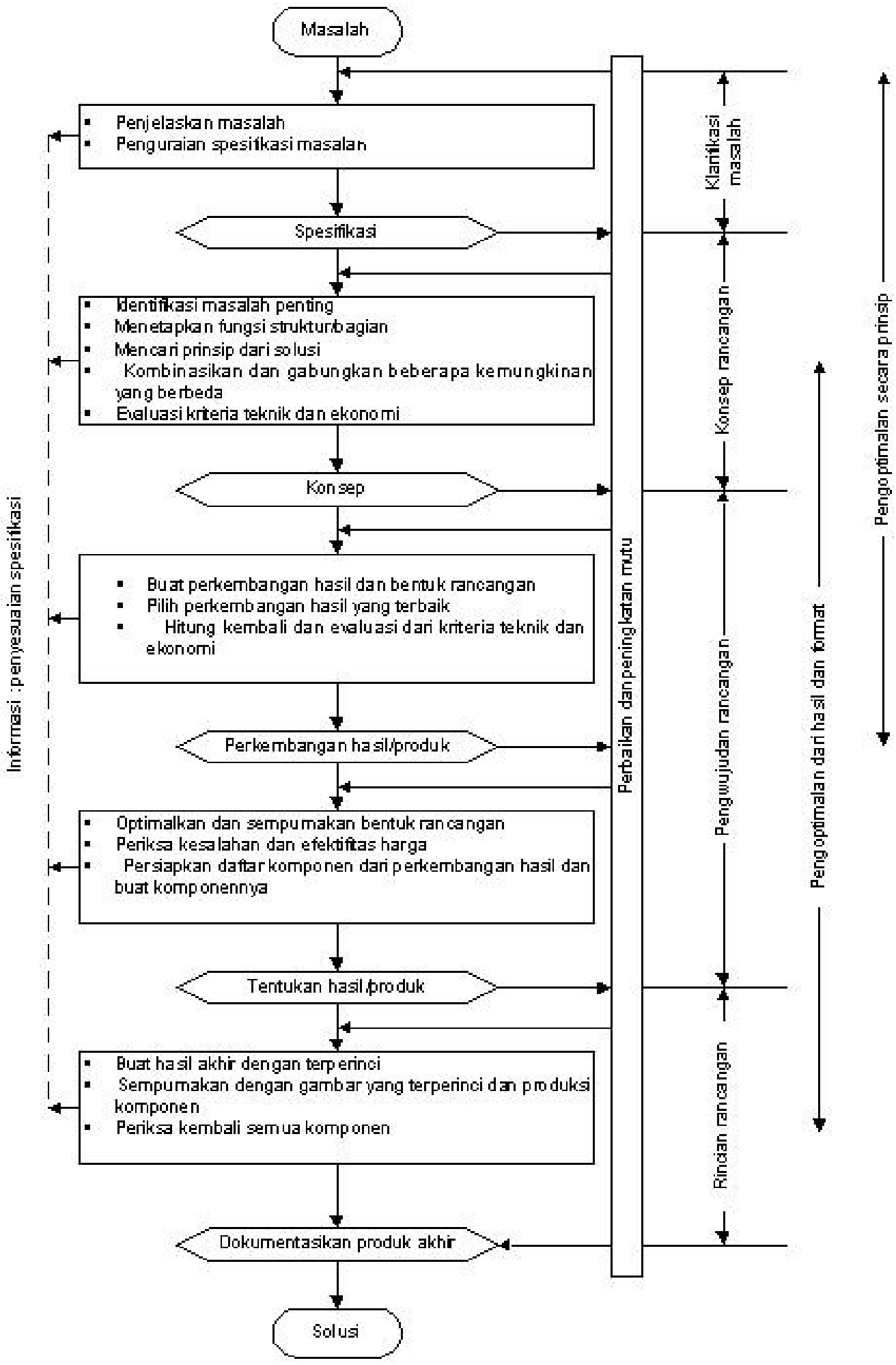

Gambar 1. Diagram Alir Proses Perancangan

(Sumber: Pahl \& Beitz, 2013) 


\section{HASIL DAN PEMBAHASAN}

Alat pelorot malam yang selama ini digunakan oleh industri batik ditampilkan pada Gambar 2. Perancangan alat pelorot malam dibuat berdasarkan kriteria yang diinginkan industri batik. Kriteria yang diinginkan yaitu meningkatkan produktivitas, merancang alat yang efektif, alat mudah dioperasikan, mengurangi kelelahan pekerja dan resiko cidera. Hasil yang didapatkan dalam perancangan dan penjelasan tugas dijadikan konsep untuk perancangan alat. Hasil perancangan alat pelorot malam pada penelitian ini ditampilkan pada Gambar 3.

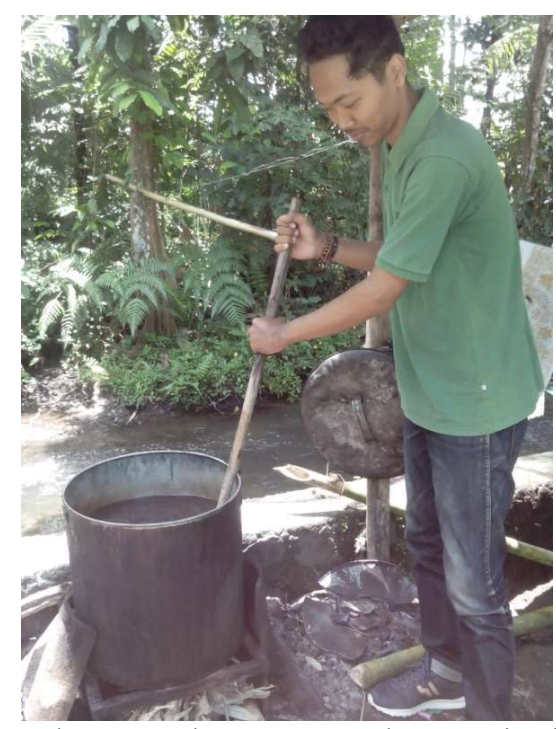

Gambar 2. Alat Pelorot Malam yang Selama Ini Digunakan Industri

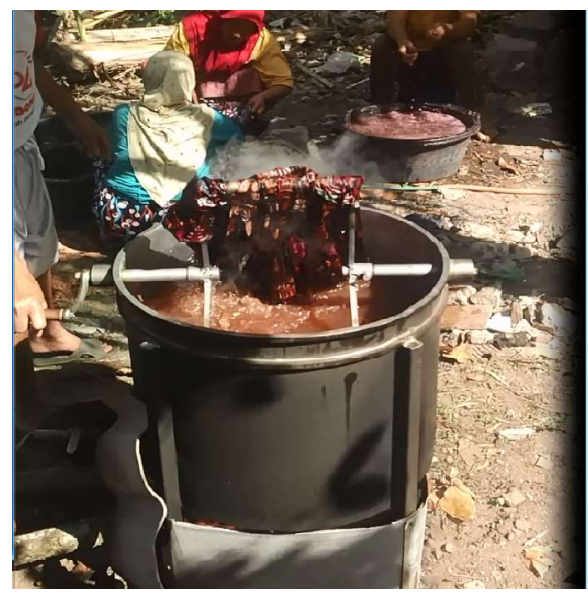

Gambar 3. Alat Pelorot Malam Hasil Perancangan 
Hasil penelitian menunjukan bahwa rata-rata waktu proses yang dihasilkan alat lama sebesar 4,38 menit untuk melorotkan 1 kain batik. Sedangkan hasil dari alat pelorotan baru memerlukan waktu rata-rata 3,77 menit untuk melorotkan empat kain batik. Hal ini menunjukan bahwa alat lama masih belum efisien dan alat pelorotan baru hasil rancangan dapat meningkatkan produktivitas industri batik.

Hasil pengujian untuk uji kelelahan secara objektif alat pelorotan lama memilki rata-rata sebesar 53,60\% yaitu lebih besar dari kondisi normal sebesar $50 \%$. Hal ini menunjukkan perlu adanya perbaikan. Setelah dilakukan perbaikan, alat pelorotan baru memiliki rata-rata $42,61 \%$, yang berarti dapat mengurangi tingkat kekelahan.

Hasil uji kelelahan secara subjektif mempengaruhi 3 jenis kelelahan yaitu kelelahan kegiatan, penurunan motivasi, dan kelelahan fisik. Kelelahan kegiatan dengan hasil rata-rata 3,73 yang berarti rendahnya tingkat kelelahan kegiatan terhadap sebagian besar responden. Kelelahan motivasi dengan hasil rata-rata 3,83 yang berarti rendahnya tingkat kelelahan motivasi terhadap sebagian besar responden. Kelelahan fisik dengan hasil rata-rata 3,66 yang berarti rendahnya tingkat kelelahan fisik terhadap sebagian besar responden.

Pengujian tingkat kepuasan operator untuk pengoperasian alat pelorotan sebesar 4,66 yang berarti sebagian besar responden mudah dalam pengoperasian alat pelorotan malam. Tingkat kenyamanan alat pelorotan sebesar 4 yang berarti sebagian besar responden nyaman menggunakan alat pelorotan. Resiko cidera alat sebesar 3,33 yang berarti sebagian besar responden dalam melakukan pelorotan masih memungkinkan cidera. Tingkat kemudahan dalam perawatan alat sebesar 4 yang berarti sebagian besar responden mudah dalam merawat alat pelorotan.

\section{KESIMPULAN}

Alat pelorotan malam/ lilin untuk Industri Batik Plalangan berhasil dikembangkan menggunakan pendekatan Pahl and Beitz. Alat ini lebih efisien, mudah dioperasikan, praktis, tidak membuat pekerja cepat lelah, dan dapat mengurangi tingkat cidera. Alat ini dapat meminimasi waktu proses menjadi 3,77 menit/ empat lembar kain batik. Selain itu alat ini memberikan tingkat kelelahan kepada operator lebih rendah yaitu dari $53,60 \%$ menjadi $42,61 \%$.

\section{DAFTAR PUSTAKA}

Imdaadi, T., 2015, Perancangan Alat Pemotong Padi untuk Mempercepat Waktu Pemotongan dengan Metode Pahl and Beitz (Studi Kasus Di Lahan Pertanian Padi, Desa Baturetno Kabupaten Bantul), Disertasi, UPN "VETERAN" Yogyakarta.

Pahl, G. and Beitz, W., 2013, Engineering design: a systematic approach, Springer Science \& Business Media. 